\title{
Effect of Sn Addition in the Microstructure Refinement and Corrosion Resistance of Cu-Zr- Al-Ag Alloy
}

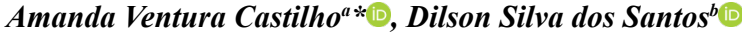 \\ ${ }^{a}$ Centro de Tecnologia - Ilha do Fundão, Programa de Engenharia da Nanotecnologia, Universidade \\ Federal do Rio de Janeiro, Caixa Postal 68505, Rio de Janeiro, RJ, Brasil \\ ${ }^{b}$ Programa de Engenharia Metalúrgica e de Materiais, Universidade Federal do Rio de Janeiro, Caixa \\ Postal 68505, Rio de Janeiro, RJ, Brasil
}

Received: December 24, 2017; Revised: January 07, 2018; Accepted: February 15, 2019

In this paper, a composition of known high glass-forming ability, $\mathrm{Cu}_{42} \mathrm{Zr}_{42} \mathrm{Al}_{8} \mathrm{Ag}_{8}$ and a novel $\mathrm{Cu}_{42} \mathrm{Zr}_{42} \mathrm{Al}_{8} \mathrm{Ag}_{4} \mathrm{Sn}_{4}$, were produced by suction-casting. After rapid solidification of both alloys, $\mathrm{X}$-ray diffraction patterns along with crystallite size estimation by Scherrer equation and scanning electron microscopy images revealed a refined microstructure, composed mainly by $\mathrm{AlCu}_{2} \mathrm{Zr}, \mathrm{CuZr}_{2}$ and $\mathrm{Cu}_{10} \mathrm{Zr}_{7}$ phases. Transmission electron microscopy indicated the presence of small crystalline precipitates in the $\mathrm{Cu}_{42} \mathrm{Zr}_{42} \mathrm{Al}_{8} \mathrm{Ag}_{4} \mathrm{Sn}_{4}$ suction-casted sample. Polarization curves showed a higher passivation current in the $\mathrm{Sn}$ containing sample, suggesting a decrease in corrosion resistance.

Keywords: Nanotechnology, Nanomaterials, Microstructural refinement, Glass-forming ability, Bulk Metallic Glasses.

\section{Introduction}

Bulk metallic glasses, BMG, and nanocrystalline alloys represent new possibilities for microstructural engineering of materials. One way to measure the glass forming ability (GFA) is the critical cooling rate to avoid the "nose" of the time-temperature-transition (TTT) curve for a specific alloy. The nucleation and growth mechanism determines the shape and position of the TTT curve in the temperaturetime space. In most of cases, by avoiding the nose, external infuencens prevent inherent homogeneous crystallization ${ }^{1-4}$. If a critical cooling rate is achieved for a stated dimension ${ }^{5}$, compositions that possess high glass-forming ability can be produced as amorphous solids by rapid solidification processes, such as suction-casting ${ }^{6}$.

Systems that possess high GFA usually follow the conventional proposed criteria involving relations between crystallization, melting and glass transition temperatures, along with a negative heat of mixing, topological factors, critical cooling rate and critical dimension ${ }^{7}$. Eutectic Copper-Zirconium based alloys exhibit high GFA, the rapid solidification of these alloys can lead to the formation of BMG's ${ }^{8-10}$. Near eutectic $\mathrm{Cu}-\mathrm{Zr}$ based systems have been extensively studied due to their interesting properties, such as high corrosion resistance ${ }^{11,12}$ and good mechanical strength ${ }^{13,14}$. These systems are thus useful as engineering materials. $\mathrm{Zr}-(\mathrm{Cu}-\mathrm{Ag})-\mathrm{Al}$ bulk metallic glasses can be produced by suction-casting in copper molds with large diameters, the $\mathrm{Zr}_{48} \mathrm{Cu}_{38.5} \mathrm{Ag}_{5.5} \mathrm{Al}_{8}$ composition achieving $20 \mathrm{~mm}^{15}$ and the $\mathrm{Cu}_{43} \mathrm{Zr}_{43} \mathrm{Al}_{7} \mathrm{Ag}_{7}, 8 \mathrm{~mm}^{16}$.

*e-mail: amandaventura@metalmat.ufrj.br
However, contrary to crystals, BMGs suffer from a lack of crystalline defects such as dislocations and commonly do not present ductility in uniaxial mechanical tests ${ }^{17}$. In such case, BMGs lead to shear bands formation, localizing the plastic deformation ${ }^{18}$. This restricts the overall plasticity of BMGs in most cases to less than $1 \%$ and hampers the use of BMGs as a structural material in several possible utilization. For the sake of overcoming the problem of the poor plasticity of BMG at room temperature and allow the development of structural materials, attempts have been concentrated on the production of BMG composites. A diversity of composite materials have been produced either by adding a crystalline phase into the liquefied $\mathrm{BMG}{ }^{19}$ or by in situ precipitation of crystalline phases throughout partial crystallization ${ }^{20,21}$. Such a methodology allows enhanced plasticity in BMG composites by generating multiple shear bands, which will interact with each other, thus limiting a single shear band from crossing within the material.

A simple way of producing such a composite is by not reaching the critical cooling rate. The product of solidification may then present a second phase embedded in the amorphous alloy, improving the yield ${ }^{22}$ and flexural strength ${ }^{23}$, and ductility ${ }^{24}$.

Sn was chosen as substitutional element due to the improved corrosion resistance in Zirconium based alloys when small amount of this element is added ${ }^{25}$ and its low cost in comparison to Ag. Furthermore, the atomic radius and electronegativity of $\mathrm{Ag}$ and $\mathrm{Sn}$ are very similar, thus allowing keeping the good GFA of the alloy.

This work aims to synthesize by a rapid solidification method $\mathrm{Cu}_{42} \mathrm{Zr}_{42} \mathrm{Al}_{8} \mathrm{Ag}_{8}$ and $\mathrm{Cu}_{42} \mathrm{Zr}_{42} \mathrm{Al}_{8} \mathrm{Ag}_{4} \mathrm{Sn}_{4}$ alloys, infer about the microstructure refinement and corrosion resistance 
effects promoted by $\mathrm{Sn}$ addition. The rapidly solidified alloys were produced by the suction-casting method and characterized by X-ray diffraction (XRD) along with crystallite size estimation by Scherrer equation, scanning electron microscopy (SEM) and transmission electron microscopy (TEM) techniques. Polarization curves were also obtained for corrosion resistance inference.

\section{Experimental}

An arc-melter Edmund Bühler GmbH furnace, with $5 \mathrm{~mm}$ diameter copper mold, was used to produce suction-casted samples of $\mathrm{Cu}_{42} \mathrm{Zr}_{42} \mathrm{Al}_{8} \mathrm{Ag}_{8}$ and of the proposed composition $\mathrm{Cu}_{42} \mathrm{Zr}_{42} \mathrm{Al}_{8} \mathrm{Ag}_{4} \mathrm{Sn}_{4}$. To crystallize the alloys during suction casting the water flow in the refrigeration system was reduced, also reducing the exchanged heat. Melting processes were performed under Argon atmosphere. To prepare these alloys Cu powder (99.99\% purity), $\mathrm{Zr}$ nuclear quality $99.9 \%$ purity, Al $99.99 \%$ purity, Ag $99.99 \%$ purity and Sn $99.9 \%$ purity were used. To solve the problem of Sn evaporation, $\mathrm{Zr}$ was positioned above $\mathrm{Sn}$ and these elements were previously molten together, in order to form the $\alpha-\mathrm{Zr}$ and $\mathrm{Zr}_{4} \mathrm{Sn}$ phases in equilibrium, with the melting temperature of approximately $1000^{\circ} \mathrm{C}^{26}$. After this step, this material was molten along with other elements.

XRD measurements were performed in G8-Discover Bruker equipment with $\mathrm{Cu}-\mathrm{K} \alpha$ radiation, $\lambda=1.5418 \AA$. Present phases were identified by comparison with the XRD patterns simulated by Powder Cell software, based on crystallographic data obtained from literature ${ }^{27,28,29}$. The Scherrer equation was used for crystallite size estimation from the XRD patterns, along with Gaussian fittings. The chosen shape factor was $\mathrm{k}=0.9$. The uncertainties were calculated using errors related to the centers of peaks and the widths. SEM images in back-scattered electrons mode were acquired with a Jeol JSM 6460LV. TEM images of the $\mathrm{Cu}_{42} \mathrm{Zr}_{42} \mathrm{Al}_{8} \mathrm{Ag}_{4} \mathrm{Sn}_{4}$ suction-casted sample were acquired with FEI TECNAI G2 F20 microscope. The potentiodynamic polarization curves were performed in $\mathrm{H}_{2} \mathrm{SO}_{4} 1 \mathrm{M}$ solution under open air at room temperature and conducted in a three-electrode cell using a platinum counter electrode and a $\mathrm{Hg} / \mathrm{HgCl}_{2}$ reference electrode. These curves were measured at a rate of $600 \mathrm{mV} / \mathrm{h}$ after open-circuit immersion for about $30 \mathrm{~min}$ when the open-circuit potential became almost steady. The minimum and maximum applied potential were $-2 \mathrm{~V}$ and $2 \mathrm{~V}$.

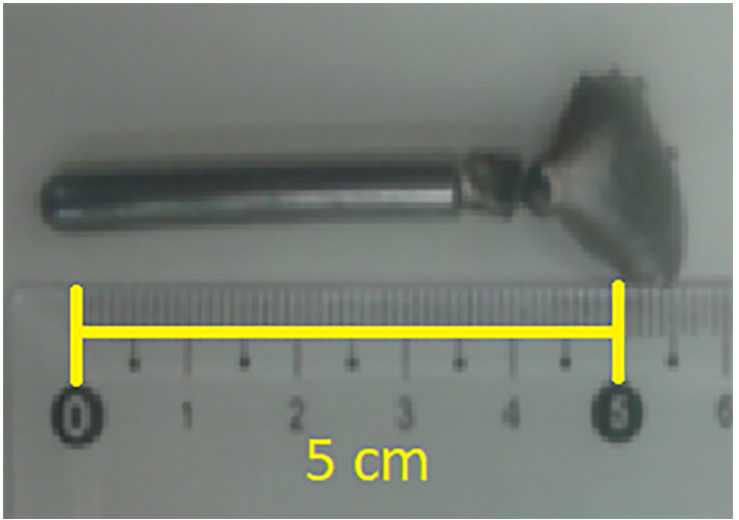

Figure 1. $\mathrm{Cu}_{42} \mathrm{Zr}_{42} \mathrm{Al}_{8} \mathrm{Ag}_{4} \mathrm{Sn}_{4}$ suction-casted sample.

\section{Results and Discussions}

Figure 1 shows the $\mathrm{Cu}_{42} \mathrm{Zr}_{42} \mathrm{Al}_{8} \mathrm{Ag}_{4} \mathrm{Sn}_{4}$ suction-casted sample. Figures 2 and 3 show the diffraction patterns for the $\mathrm{Cu}_{42} \mathrm{Zr}_{42} \mathrm{Al}_{8} \mathrm{Ag}_{8}$ and the $\mathrm{Cu}_{42} \mathrm{Zr}_{42} \mathrm{Al}_{8} \mathrm{Ag}_{4} \mathrm{Sn}_{4}$ samples, under the two studied conditions. $\mathrm{Cu}_{10} \mathrm{Zr}_{7}$ was markedly the most present phase. $\mathrm{AlCu}_{2} \mathrm{Zr}$ and $\mathrm{CuZr}{ }_{2}$ peaks were also identified in all four samples. $\mathrm{CuZr}_{2}$ and $\mathrm{Cu}_{10} \mathrm{Zr}_{7}$ are present in the $\mathrm{Cu}-\mathrm{Zr}$ binary diagram ${ }^{30}$, and these phases along with of $\mathrm{AlCu}_{2} \mathrm{Zr}$ are reported in the literature after copper mold casting of $\mathrm{Cu}_{40} \mathrm{Zr}_{44} \mathrm{Al}_{8} \mathrm{Ag}_{8}{ }^{28}$. The red arrows in Figures 2 and 3 point to the analyzed peaks, used to generate the full width at half maximum (FWHM) and crystallite size data in Table 1. The suction-casting process led to remarkably higher FWHM and smaller crystallite sizes for all analyzed peaks in both compositions. The rapid solidification process promoted great microstructure refinement instead of leading to the formation of amorphous alloys. It can also be noted for $\mathrm{AlCu}_{2} \mathrm{Zr}, \mathrm{CuZr}$ and $\mathrm{Cu}_{10} \mathrm{Zr}_{7}$ analyzed peaks, that the rapid cooling promoted similar crystallite sizes for both compositions considering the uncertainties. The addition of $\mathrm{Sn}$ in $\mathrm{Cu}-\mathrm{Zr}$-Al-Ag system did not lead to a significant difference in microstructure refinement obtained by the performed suction-casting.

The back-scattered electrons SEM image of the $\mathrm{Cu}_{42} \mathrm{Zr}_{42} \mathrm{Al}_{8} \mathrm{Ag}_{8}$ arc-melted sample (Figure 4.a) presents two main types of precipitated morphologies: "drop-like" and "cross", dispersed in the matrix. It is noteworthy that the "cross" morphology resembles dendritic structures. After the suction-casting process, the scanning electron microscopy image (Figure 4.b) shows more refined "cross" structures, with the "drop-like" structure not exhibiting a substantial 

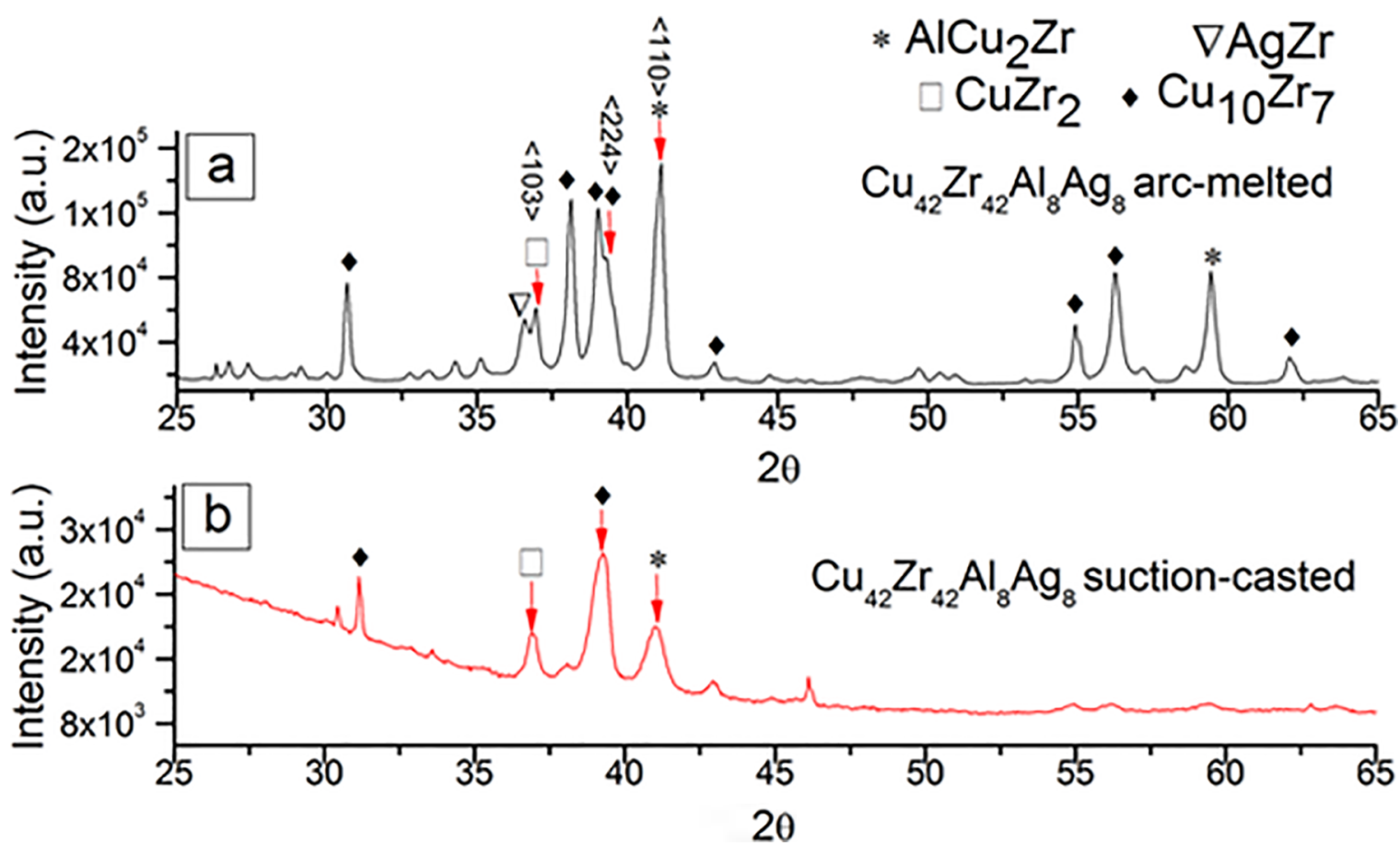

Figure 2. X-ray diffractograms of $\mathrm{Cu}_{42} \mathrm{Zr}_{42} \mathrm{Al}_{8} \mathrm{Ag}_{8}$, (a) arc-melted and (b) suction-casted. The red arrows indicate the selected peaks for crystallite size estimation.

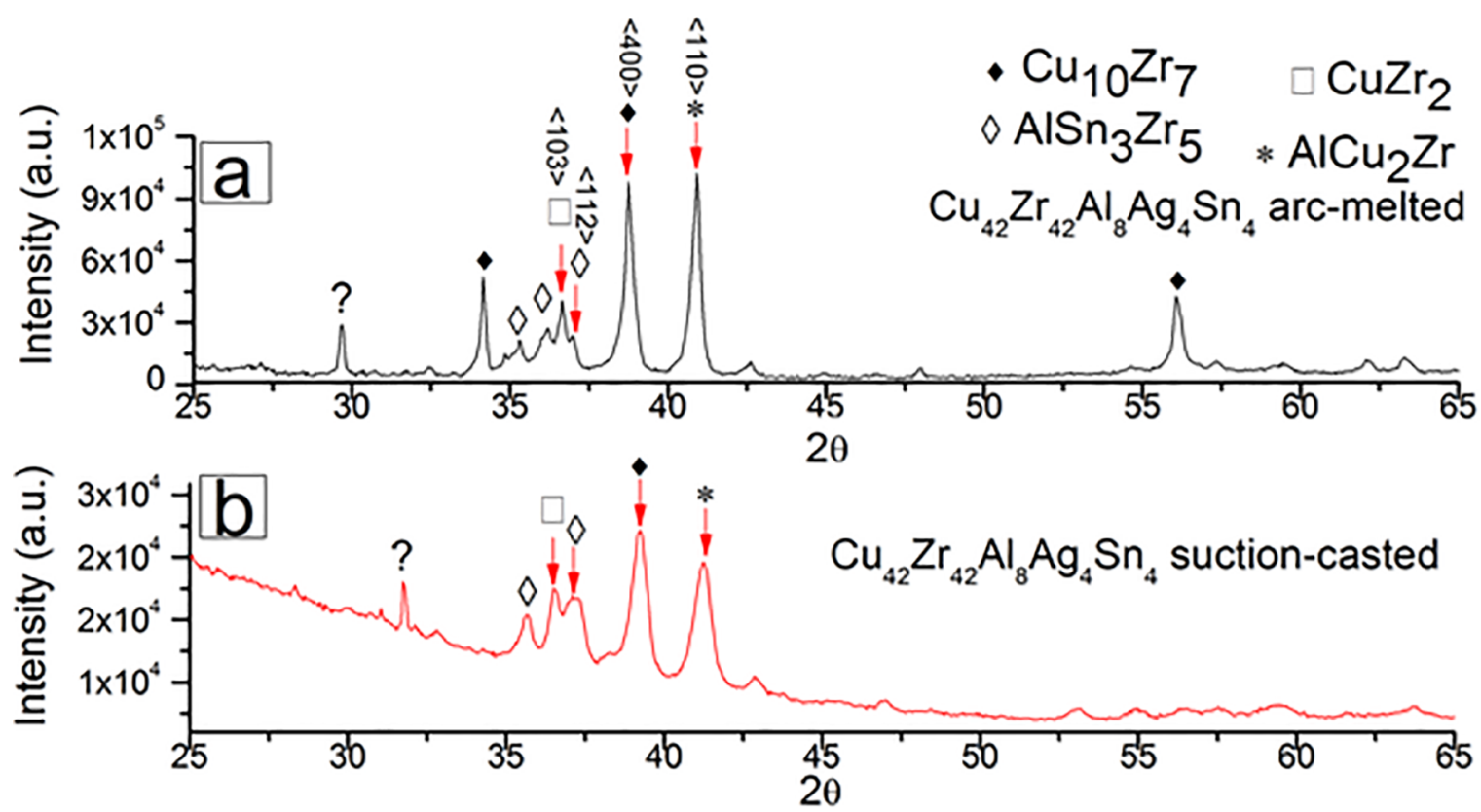

Figure 3. X-ray diffractograms of $\mathrm{Cu}_{42} \mathrm{Zr}_{42} \mathrm{Al}_{8} \mathrm{Ag}_{4} \mathrm{Sn}_{4}$, (a) arc-melted and (b) suction-casted. The red arrows indicate the selected peaks for crystallite size estimation. 
Table 1. Results of full width at half maximum (FWHM) and crystallite sizes for arc-melted (AM) and suction-casted (SC) systems, with uncertainties $(\sigma)$.

\begin{tabular}{|c|c|c|c|c|c|}
\hline & Peak & System & FWHM ( $\left(^{\circ}\right)$ & $\begin{array}{c}\text { Crystallite size } \\
\text { (nm) }\end{array}$ & $\begin{array}{c}\sigma \text { Cristalite } \\
\operatorname{size}(n m)\end{array}$ \\
\hline \multirow{6}{*}{$\mathrm{Cu}_{42} \mathrm{Zr}_{42} \mathrm{Al}_{8} \mathrm{Ag}_{8}$} & $\mathrm{AlCu}_{2} \mathrm{Zr}$ & $\mathrm{AM}$ & 0,3776 & 28 & 1 \\
\hline & $\mathrm{AlCu}_{2} \mathrm{Zr}$ & $\mathrm{SC}$ & 0,6707 & 16 & 1 \\
\hline & $\mathrm{Cu}_{10} \mathrm{Zr}_{7}$ & $\mathrm{AM}$ & 0,3963 & 26 & 3 \\
\hline & $\mathrm{Cu}_{10} \mathrm{Zr}_{7}$ & $\mathrm{SC}$ & 0,6352 & 16 & 1 \\
\hline & $\mathrm{CuZr}_{2}$ & $\mathrm{AM}$ & 0,2324 & 45 & 1 \\
\hline & $\mathrm{CuZr}_{2}$ & $\mathrm{SC}$ & 0,4060 & 24 & 1 \\
\hline \multirow{8}{*}{$\mathrm{Cu}_{42} \mathrm{Zr}_{42} \mathrm{Al}_{8} \mathrm{Ag}_{4} \mathrm{Sn}_{4}$} & $\mathrm{AlCu}_{2} \mathrm{Zr}$ & $\mathrm{AM}$ & 0,3607 & 29 & 1 \\
\hline & $\mathrm{AlCu}_{2} \mathrm{Zr}$ & $\mathrm{SC}$ & 0,6278 & 17 & 1 \\
\hline & $\mathrm{Cu}_{10} \mathrm{Zr}_{7}$ & $\mathrm{AM}$ & 0,3753 & 27 & 1 \\
\hline & $\mathrm{Cu}_{10} \mathrm{Zr}_{7}$ & $\mathrm{SC}$ & 0,5504 & 19 & 1 \\
\hline & $\mathrm{CuZr}_{2}$ & $\mathrm{AM}$ & 0,2588 & 38 & 3 \\
\hline & $\mathrm{CuZr}_{2}$ & $\mathrm{SC}$ & 0,4028 & 21 & 1 \\
\hline & $\mathrm{AlSn}_{3} \mathrm{Zr}_{5}$ & $\mathrm{AM}$ & 0,2410 & 41 & 5 \\
\hline & $\mathrm{AlSn}_{3} \mathrm{Zr}_{5}$ & $\mathrm{SC}$ & 0,6047 & 16 & 1 \\
\hline
\end{tabular}

difference. A study of the microstructure of $\mathrm{Cu}_{40} \mathrm{Zr}_{44} \mathrm{Al}_{8} \mathrm{Ag}_{8}$ rapidly solidified in copper mold ${ }^{28}$ reported the presence of a "skeletal phase" with an approximate stoichiometry of $\mathrm{CuZr} r_{2}$, which resembles the observed "cross" structure. The existence of a "blocky phase" is also reported with a stoichiometry of approximately $\mathrm{Cu}_{10} \mathrm{Zr}_{7}$, resembling the "droplike" structures observed in this study. The points selected for EDS analysis of $\mathrm{Cu}_{42} \mathrm{Zr}_{42} \mathrm{Al}_{8} \mathrm{Ag}_{8}$ suction-casted sample are shown in Figure 5.a and the atomic percent results are in Table 2. Point 1 is marked inside the "drop-like" precipitate and point 2 in the matrix. The results of the EDS analysis allow for inferring that all elements are present in both regions, and point 1 contains less $\mathrm{Cu}$ and $\mathrm{Ag}$. These regions could not be assigned to specific phases. The presence of Oxygen in point 1 is probably due to an oxidation process.

White oriented columns, cross structures, and other structures without defined shape are dispersed inside the matrix, in the microstructure of the $\mathrm{Cu}_{42} \mathrm{Zr}_{42} \mathrm{Al}_{8} \mathrm{Ag}_{4} \mathrm{Sn}_{4}$ arcmelted sample (Figure 4.c). After rapid solidification, the formation of white oriented columnar structures is suppressed and the white phase is quenched into smaller structures (Figure 4.d). To investigate the composition of the different regions of the $\mathrm{Cu}_{42} \mathrm{Zr}_{42} \mathrm{Al}_{8} \mathrm{Ag}_{4} \mathrm{Sn}_{4}$ suction-casted sample, EDS analysis was performed. The selected points for EDS analyses and results are shown in figure 5.b and Table 2. Point 3 is marked on the white phase and presents $\mathrm{Sn}, \mathrm{Zr}$,
$\mathrm{Cu}$, and $\mathrm{Al}$ in its composition. Point 4 is marked inside the matrix and presents $\mathrm{Ag}, \mathrm{Zr}, \mathrm{Cu}$ and $\mathrm{Al}$ in its composition. Therefore, the white phase contains Sn and not Ag, while in the matrix region this relation is the opposite. The relevant atomic percent of Sn exhibited on point 3 suggests that the white columnar phases contain this element and these structures may contain the $\mathrm{AlSn}_{3} \mathrm{Zr}_{5}$ phase. Figures 4.e and 4.f show the TEM image of $\mathrm{Cu}_{42} \mathrm{Zr}_{42} \mathrm{Al}_{8} \mathrm{Ag}_{4} \mathrm{Sn}_{4}$ suction-casted sample and the SAEDP. The presence of small crystalline precipitates in grain boundaries, pointed by red arrows, is remarkable. Furthermore, in SAEDP, small dispersive points in diffusive halo can be noted. This behavior can be related to small crystalline structures ${ }^{31,32}$.

Figure 6 presents the polarization curves and the Table 3 displays the passivation current (I) for all analyzed samples. For $\mathrm{Cu}_{42} \mathrm{Zr}_{42} \mathrm{Al}_{8} \mathrm{Ag}_{8}$ composition, the peak at the beginning of anodic polarization and passivation current became lower after the suction-casting. This behavior suggests better corrosion resistance after microstructure refinement ${ }^{11}$, as expected. Considering the $\mathrm{Cu}_{42} \mathrm{Zr}_{42} \mathrm{Al}_{8} \mathrm{Ag}_{4} \mathrm{Sn}_{4}$ composition, although the suction-casted sample presented a lower peak at beginning of anodic polarization, the passivation current was higher. This suggests that the microstructure refinement promoted by rapid solidification process in the proposed composition did not lead to an increase in corrosion resistance. The passivation currents for arc-melted and suction-casted 

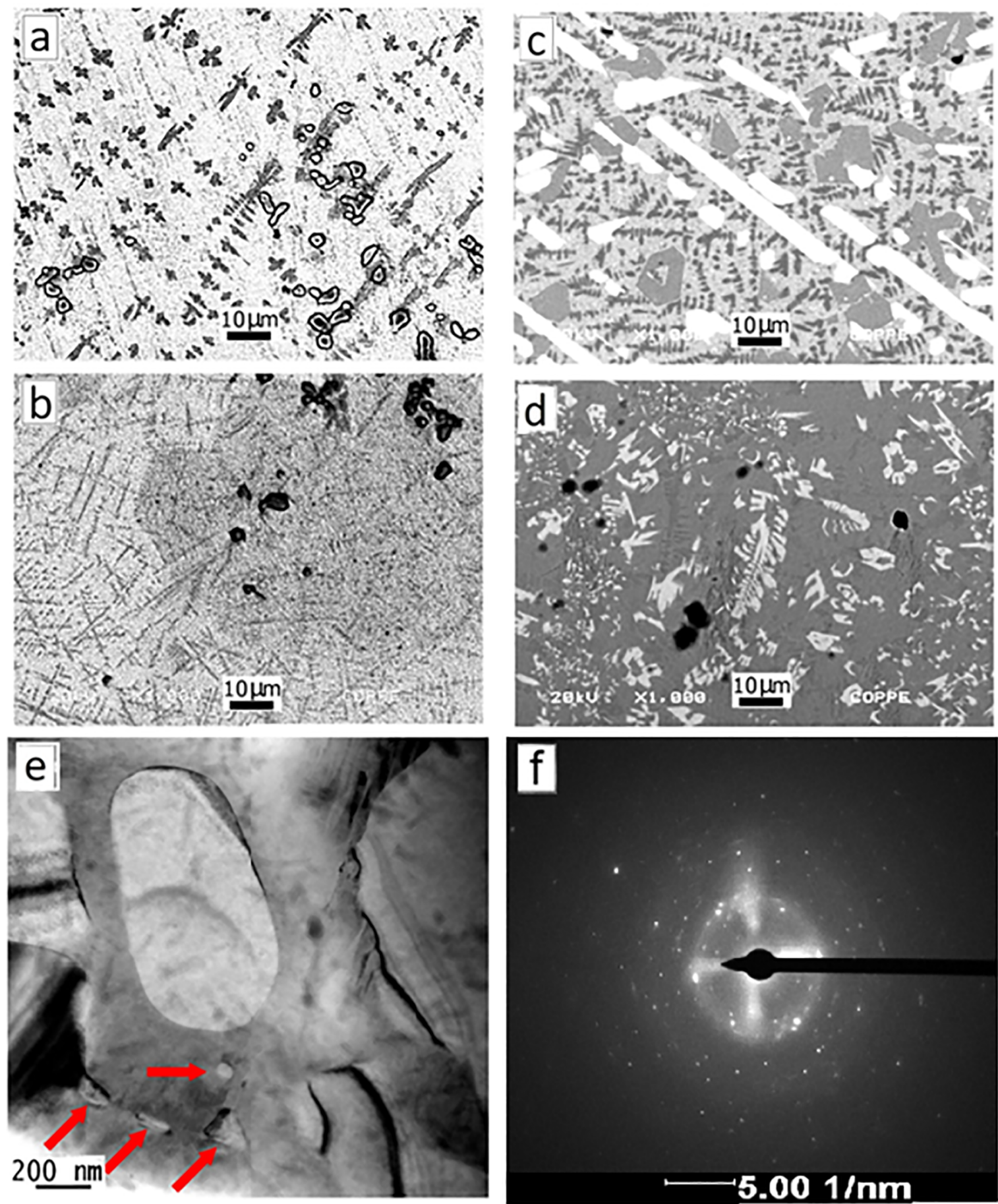

Figure 4. From a-b images of $\mathrm{Cu}_{42} \mathrm{Zr}_{42} \mathrm{Al}_{8} \mathrm{Ag}_{8}$ samples: $\mathrm{SEM}$ of arc-melted and $\mathrm{SEM}$ of suction-casted, respectively. From c-d images of

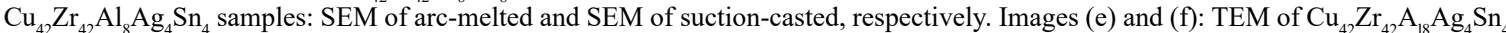
suction-casted sample with nanocrystalline precipitates pointed by red arrows and its SAEDP, respectively. 


\section{a}
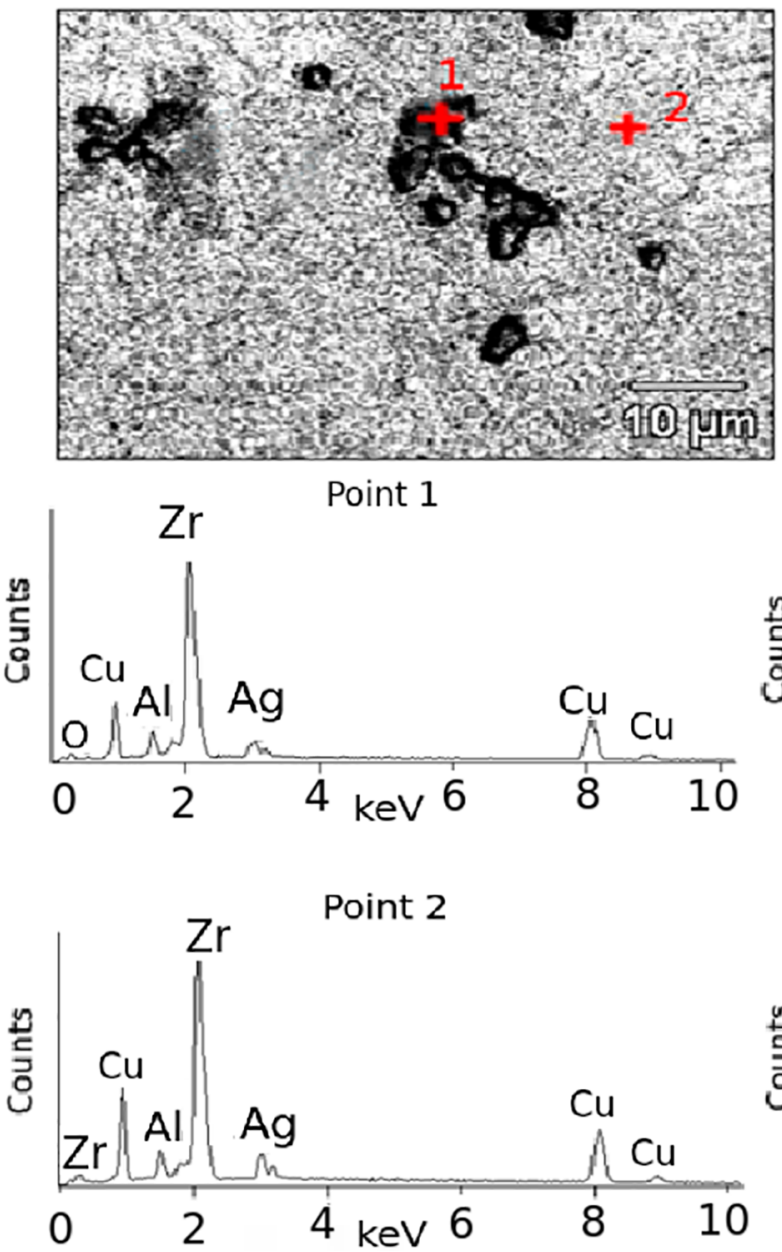
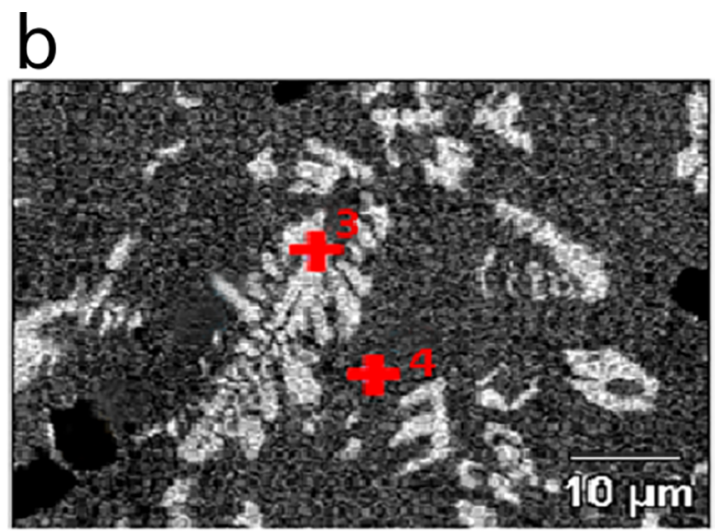

Point 3

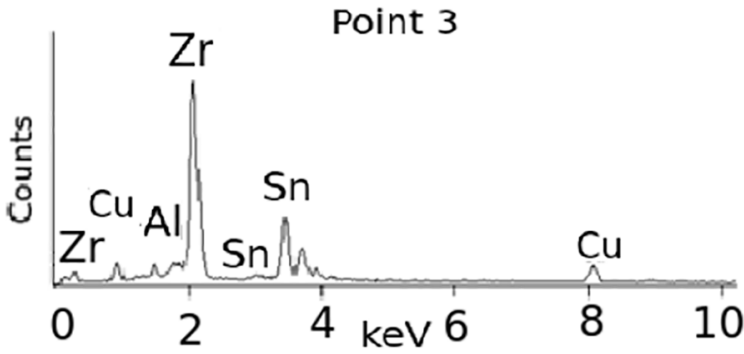

Point 4

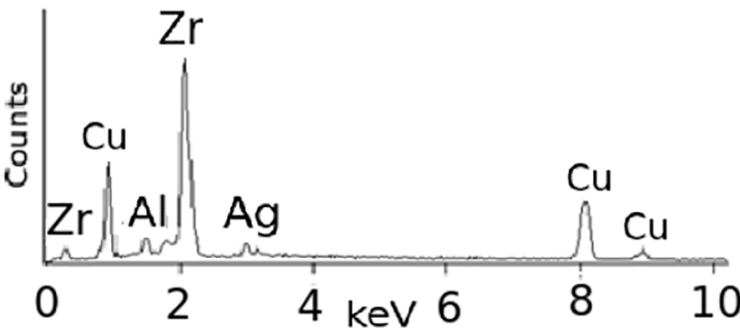

Figure 5. Selected point for EDS analysis and results. In a: $\mathrm{Cu}_{42} \mathrm{Zr}_{42} \mathrm{Al}_{8} \mathrm{Ag}_{8}$ suction-casted sample, in b: $\mathrm{Cu}_{42} \mathrm{Zr}_{42} \mathrm{Al}_{8} \mathrm{Ag}_{4} \mathrm{Sn}_{4}$ suction-casted sample.

Table 2. EDS results of atomic percentages, for points 1-4, indicated in figure 5 .

\begin{tabular}{ccccccc}
\hline \multirow{2}{*}{ Point } & \multicolumn{7}{c}{ Atomic \% } \\
\cline { 2 - 7 } & $\boldsymbol{O}$ & $\boldsymbol{A l}$ & $\boldsymbol{C u}$ & $\boldsymbol{Z} \boldsymbol{r}$ & $\boldsymbol{A g}$ & $\boldsymbol{S n}$ \\
\hline $\mathbf{1}$ & 5.04 & 8,99 & 36,77 & 43,79 & 5,41 & -- \\
$\mathbf{2}$ & -- & 8,45 & 42.41 & 40,95 & 8,19 & -- \\
$\mathbf{3}$ & -- & 3,74 & 17,07 & 50,94 & -- & 28,25 \\
$\mathbf{4}$ & -- & 7,05 & 52,13 & 37,53 & 3,29 & -- \\
\hline
\end{tabular}

samples increased with Sn addition, this allows inferring that the Sn addition decreased the corrosion resistance of arc-melted and suction-casted samples.

\section{Conclusions}

The $\mathrm{Cu}_{42} \mathrm{Zr}_{42} \mathrm{Al}_{8} \mathrm{Ag}_{8}$ and the novel $\mathrm{Cu}_{42} \mathrm{Zr}_{42} \mathrm{Al}_{8} \mathrm{Ag}_{4} \mathrm{Sn}_{4}$ suction-casted samples presented great microstructural refinement, as shown by XRD, SEM and crystallite size estimation. After rapid solidification, the crystallite size estimation of the common peaks resulted in similar values. The rapid solidification of the proposed composition led to the formation of small crystalline precipitates at grain boundaries, as noted in TEM images. The addition of Sn led to high passivation currents. These results allow for inferring that Sn addition did not clearly affect microstructural refinement, however, it decreased the corrosion resistance. 

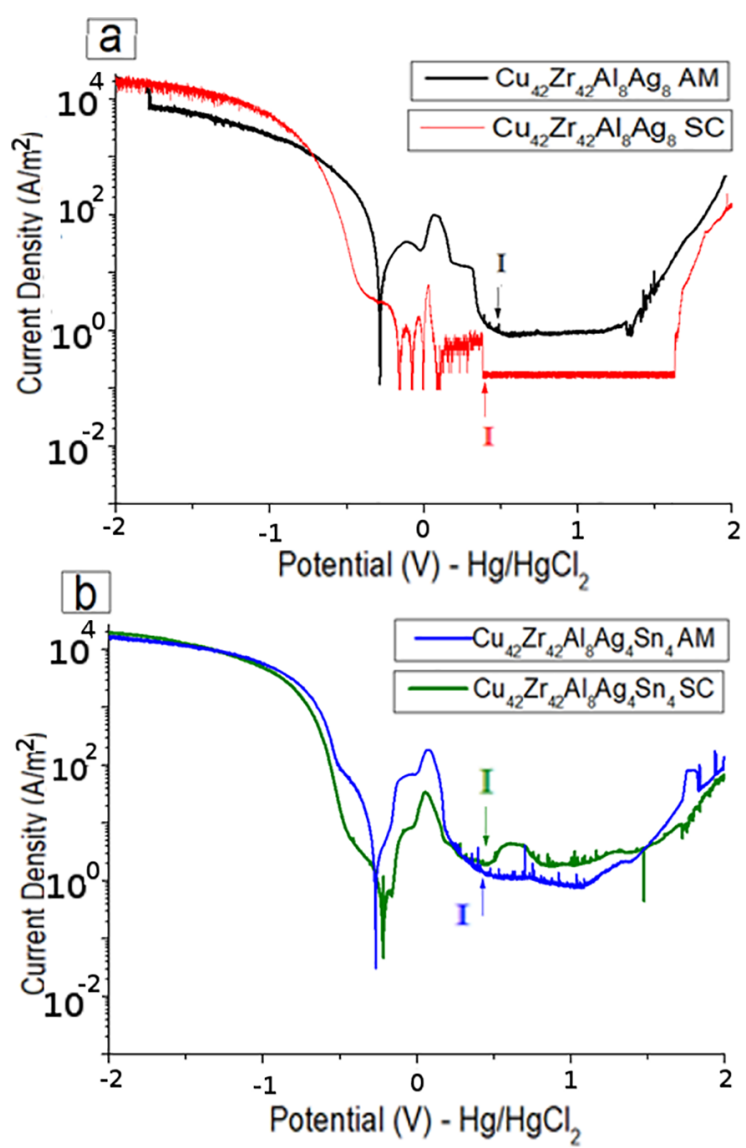

Figure 6. Potentiodynamic polarization curves for arc-melted (AM) and suction-casted (SC) samples. The selected points for passivation current density (I) acquisition are indicated by arrows.

Table 3. Obtained passivation currents for arc-melted (AM) and suction-casted (SC) samples.

\begin{tabular}{lc}
\hline Sample & $\mathrm{I}\left(\mathrm{A} / \mathrm{m}^{2}\right)$ \\
\hline $\mathrm{Cu}_{42} \mathrm{Zr}_{42} \mathrm{Al}_{8} \mathrm{Ag}_{8} \mathrm{AM}$ & 0,86 \\
$\mathrm{Cu}_{42} \mathrm{Zr}_{42} \mathrm{Al}_{8} \mathrm{Ag}_{8} \mathrm{SC}$ & 0,15 \\
$\mathrm{Cu}_{42} \mathrm{Zr}_{42} \mathrm{Al}_{8} \mathrm{Ag}_{4} \mathrm{Sn}_{4} \mathrm{AM}$ & 1,22 \\
$\mathrm{Cu}_{42} \mathrm{Zr}_{42} \mathrm{Al}_{8} \mathrm{Ag}_{4} \mathrm{Sn}_{4} \mathrm{SC}$ & 2,05 \\
\hline
\end{tabular}

\section{Acknowledgments}

We thank FAPERJ, CNPq and CAPES, for financial support and also thank the LCE laboratory of UFSCAR for performing the TEM analysis.

\section{References}

1. Drehman AJ, Greer AL. Kinetics of crystal nucleation and growth in $\mathrm{Pd}_{40} \mathrm{Ni}_{40} \mathrm{P}_{20}$ glass. Acta Metallurgica. 1984;32(3):323332.
2. Nishiyama N, Inoue A. Supercooling investigation and critical cooling rate for glass formation in Pd-Cu-Ni-P alloy. Acta Materialia. 1999;47(5):1487-1495.

3. Shen TD, Schwarz RB. Bulk ferromagnetic glasses prepared by flux melting and water quenching. Applied Physics Letters. 1999;75(1):49-51.

4. Schroers J, Yue W, Johnson WL. Heterogeneous influences on the crystallization of $\mathrm{Pd}_{43} \mathrm{Ni}_{10} \mathrm{Cu}_{27} \mathrm{P}_{20}$. Philosophical Magazine A. 2002;82(6):1207-1217.

5. Suryanarayana C, Koch CC. Nanocrystalline materials Current research and future directions. Hyperfine Interactions. 2000;130(1):5-44

6. Nishiyama N, Amiya K, Inoue A. Novel applications of bulk metallic glass for industrial products. Journal of NonCrystalline Solids. 2007;353(32-40):3615-3621.

7. Suryanarayana C, Inoue A, eds. Bulk Metallic Glasses. Boca Raton: CRC Press; 2011.

8. Tang MB, Zhao DQ, Pan MX, Wang WH. Binary Cu-Zr Bulk Metallic Glasses. Chinese Physics Letters. 2004;21(5):901903.

9. Xu D, Lohwongwatana B, Duan G, Johnson WL, Garland C. Bulk metallic glass formation in binary $\mathrm{Cu}$-rich alloy series $\mathrm{Cu}_{100-\mathrm{x}} \mathrm{Zr}_{\mathrm{x}}(\mathrm{x}=34,36,38.2,40$ at.\%) and mechanical properties of bulk $\mathrm{Cu}_{64} \mathrm{Zr}_{36}$ glass. Acta Materialia. 2004;52(9):26212624.

10. Zhang Q, Zhang W, Inoue A. New Cu-Zr-based bulk metallic glasses with large diameters of up to $1.5 \mathrm{~cm}$. Scripta Materialia. 2006;55(8):711-713.

11. Zhang W, Zhang Q, Qin C, Inoue A. Synthesis and properties of $\mathrm{Cu}-\mathrm{Zr}-\mathrm{Ag}-\mathrm{Al}$ glassy alloys with high glass-forming ability. Materials Science and Engineering: B. 2008;148(1-3):92-96.

12. Inoue A. Stabilization of metallic supercooled liquid and bulk amorphous alloys. Acta Materialia. 2000;48(1):279-306.

13. Yu P, Bai HY, Wang WH. Superior glass-forming ability of CuZr alloys from minor additions. Journal of Materials Research. 2006;21(7):1674-1679.

14. Inoue A, Zhang W. Formation, Thermal Stability and Mechanical Properties of Cu-Zr-Al Bulk Glassy Alloys. Materials Transactions. 2002;43(11):2921-2925.

15. Jiang QK, Wang XD, Nie XP, Zhang GQ, Ma H, Fecht HJ, et al. $\mathrm{Zr}-(\mathrm{Cu}, \mathrm{Ag})-\mathrm{Al}$ bulk metallic glasses. Acta Materialia. 2008;56(8):1785-1796.

16. Lee SW, Huh MY, Fleury E, Lee JC. Crystallization-induced plasticity of $\mathrm{Cu}-\mathrm{Zr}$ containing bulk amorphous alloys. Acta Materialia. 2006;54(2):349-355.

17. Schuh C, Hufnagel TC, Ramamurty U. Mechanical behavior of amorphous alloys. Acta Materialia. 2007;55(12):40674109. 
18. Zhang ZF, Eckert J, Schultz L. Difference in compressive and tensile fracture mechanisms of $\mathrm{Zr}_{59} \mathrm{Cu}_{20} \mathrm{Al}_{10} \mathrm{Ni}_{8} \mathrm{Ti}_{3}$ bulk metallic glass. Acta Materialia. 2003;51(4):1167-1179.

19. Choi-Yim H, Johnson W. Bulk metallic glass matrix composites. Applied Physics Letters. 1997;71(26):3808.

20. Hays CC, Kim CP, Johnson WL. Microstructure Controlled Shear Band Pattern Formation and Enhanced Plasticity of Bulk Metallic Glasses Containing in situ Formed Ductile Phase Dendrite Dispersions. Physical Review Letters. 2000;84(13):2901.

21. Kühn U, Eckert J, Mattern N, Schultz L. ZrNbCuNiAl bulk metallic glass matrix composites containing dendritic bec phase precipitates. Applied Physics Letters. 2002;80(14):2478.

22. Inoue A, Fan C, Saida J, Zhang T. High-strength Zr-based bulk amorphous alloys containing nanocrystalline and nanoquasicrystalline particles. Science and Technology of Advanced Materials. 2000;1(2):73-86.

23. Inoue A. Bulk amorphous and nanocrystalline alloys with high functional properties. Materials Science and Engineering: $A$. 2001;304-306:1-10.

24. Fan C, Takeuchi A, Inoue A. Preparation and Mechanical Properties of Zr-based Bulk Nanocrystalline Alloys Containing Compound and Amorphous Phases. Materials Transactions, JIM. 1999;40(1):42-51.

25. Wei J, Frankel P, Polatidis E, Blat M, Ambard A, Comstock RJ, et al. The effect of $\mathrm{Sn}$ on autoclave corrosion performance and corrosion mechanisms in $\mathrm{Zr}-\mathrm{Sn}-\mathrm{Nb}$ alloys. Acta Materialia. 2013;61(11):4200-4214.

26. Subasic N. Thermodynamic evaluation of $\mathrm{Sn}-\mathrm{Zr}$ phase diagram. Calphad. 1998;22(2):157-165.

27. Pearson WB, Villars P, Calvert LD. Pearson\&apos; Handbook of Crystallographic Data for Intermetallic Phases. Materials Park: American Society for Metals; 1985.

28. Liu Y, Blandin JJ, Suery M, Kapelski G. Effect of cooling rate on the microstructure and microhardness of the $\mathrm{CuZrAgAl}$ alloy. Materials Characterization. 2012;70:8-13.

29. Louzguine-Luzgin DV, Xie G, Zhang W, Inoue A. Influence of $\mathrm{Al}$ and $\mathrm{Ag}$ on the Devitrification Behavior of a Cu-Zr Glassy Alloy. Materials Transactions. 2007;48(8):2128-2132.

30. Zeng KJ, Hämäläinen M, Lukas HL. A new thermodynamic description of the $\mathrm{Cu}-\mathrm{Zr}$ system. Journal of Phase Equilibria. 1994;15(6):577-586.

31. Biju V, Sugathan N, Vrinda V, Salini SL. Estimation of lattice strain in nanocrystalline silver from X-ray diffraction line broadening. Journal of Materials Science. 2008;43(4):11751179 .

32. Medeiros BB, Kiminani CS, Botta WJ, Bolfarini C, Jorge Junior AM. Hot Consolidation of Partially Amorphous Cu-Ti Based Alloy: a Comparison Between Hot Extrusion and Hot Compaction by Sintering. Materials Research. 2015;18(3):448-452. 